Saudi Journal of Business and Management Studies Abbreviated Key Title: Saudi J Bus Manag Stud ISSN 2415-6663 (Print) |ISSN 2415-6671 (Online) Scholars Middle East Publishers, Dubai, United Arab Emirates Journal homepage: https://saudijournals.com

Original Research Article

\title{
The Influence of Role Ambiguity, Job Stress and Leadership on Job Satisfaction and Employee Turnover at PT. Bank BRI Syariah Samarinda
}

Salika Azzahra*, Zainal Ilmi, Adi Wijaya

Faculty of Economics and Business, Mulawarman University, J1. Kuaro, Gn. Kelua, Kec. Samarinda Ulu, Kota Samarinda, Kalimantan Timur 75119, Indonesia

DOI: $10.36348 /$ sjbms.2021.v06i01.003 $\quad$ | Received: 08.01.2021 | Accepted: 20.01.2021 | Published: 29.01 .2021

*Corresponding author: Salika Azzahra

Abstract

The purpose of this study was to determine the influence of role ambiguity, job stress and leadership quality on job satisfaction and employee turnover in PT. BRI Syariah Bank Samarinda. The study was conducted on 89 respondents, based on the distributed questionnaire results, it can be seen that the number of respondents who will be analyzed are 89 respondents. Using Partial Least Square (PLS) which supported by the WarpPLS program. Data analysis is carried out in two stages, assessing the outer model or measurement model and assessing the inner model or structural model. The findings shows that role ambiguity has significant negative correlation with employee job satisfaction, job stress has significant negative correlation with employee job satisfaction, leadership has significant positive with job satisfaction, role ambiguity has significant positive correlation with employee turnover, job stress has significant negative with employee turnover, leadership has significant negative correlation with employee turnover, job satisfaction has significant negative correlation with employee turnover.

Keywords: Role Ambiguity, Job Stress, Leadership, Job Satisfaction, Turnover.

Copyright (C) 2021 The Author(s): This is an open-access article distributed under the terms of the Creative Commons Attribution 4.0 International License (CC BY-NC 4.0) which permits unrestricted use, distribution, and reproduction in any medium for non-commercial use provided the original author and source are credited.

\section{INTRODUCTION}

Turnover has become a culture or trend in almost all industries. A high turnover rate is an undesirable situation that will ultimately lead to increased costs for recruitment, training, employee development and compensation purposes. The results of a survey by Price Waterhouse Coopers (PWC) in 2012 and 2013 Indonesia conducted on 100 senior employees in Indonesian banks show that the annual employee turnover rate tends to be high. In 2012 and 2013 the turnover rate was $5 \%$ to $20 \%$, where if the turnover rate is around 5\% and above can be said to be high when compared to the annual turnover rate in developing countries such as Singapore which has an annual turnover rate of $1.3 \%$ [1].

Job satisfaction is an important aspect for employees and company growth. According to [2] to improve company performance, the main key is to increase employee job satisfaction. Apart from job satisfaction, what affects employees is role ambiguity. Role ambiguity can be found in employees who work at the banking sector because the banking sector is a profit-oriented company that seeks to gain profits in an effective and efficient manner, so there will be many uncertainty about the role of employees. Role ambiguity will only have a bad impact on employees and will reduce the quality of human resources in the company. There are many things that affect employees in workplace and choose to stay in a company, including job satisfaction and role ambiguity. If job satisfaction is not met and role ambiguity occurs in the organization, it will have an impact on employees who want to leave the organization [3]. In addition to role ambiguity and job satisfaction, there are also factors influence employees which is job stress. Job stress is generally caused by high workloads that have high targets for each employee to achieve and that high targets affect employee job satisfaction.

The banking sector always has targets that must be achieved by its employees in order to continue to generate profits effectively and efficiently. The absence of sufficient data to support job completion, unpredictable desires from superiors and managers and a lack of confidence in employees at work can make 
Salika Azzahra et al., Saudi J Bus Manag Stud, Jan, 2021; 6(1): 15-23

employees feel they are not part of the company and less happy with their work and career, making employees do not have enough dedication to work well in the company, experiencing pressure and in the end decided to leave the company [4].

One of the Sharia banks in Indonesia is PT. Bank BRI Syariah. Based on direct observations, it has been found that employees undergo many adaptation processes to changes that occur in the organization as a whole. The banking industry, which is a profit-oriented company, is required employees to always be able to compete in an organizational environment and be able to achieve the targets and goals set by the company. Inadequate working conditions are assumed to lead to role ambiguity in employees, work stress and the influence of the type of leadership which ultimately affects employee turnover rates and employee job satisfaction levels at PT. Bank BRI Syariah Samarinda Branch.

The following data is obtained regarding the transfer of employees of PT. Bank BRI Syariah in all branch offices and work units in Indonesia:

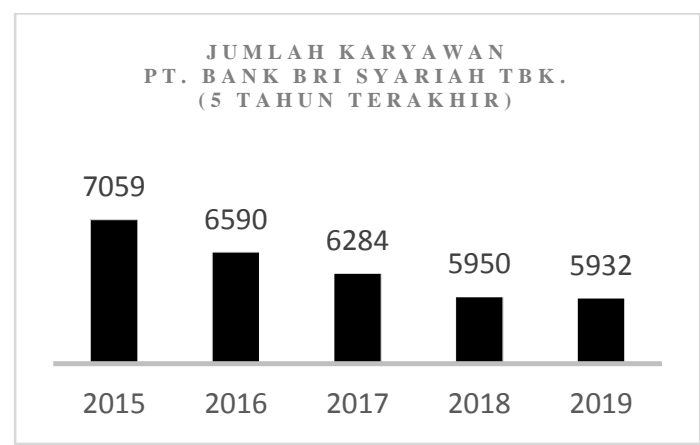

Fig-1: Number of Employees of PT. Bank BRI Syariah (2015-2019)

From Figure-1 it can be seen that there has been a decrease in the number of employees that has occurred consecutively every year in the last 5 years. Based on this background, researchers are interested to do a reasearch at PT. Bank BRI Syariah Samarinda using research variables which are role ambiguity, job stress, leadership, job satisfaction and employee turnover.

\section{LITERATURE REVIEW \\ Role Ambiguity}

Role ambiguity increases when the role for a job position is very unclear, uncertain and very poorly explained to the employee. Role ambiguity initially occurs when employees do not know for sure the expectations of the leader for the role, the requirements, procedures and methods related to the employee's job [5].

\section{Job Stress}

Job stress can cause turnover intentions [6]. According to [7] job stress is an adaptive response to external situations that produce physical, psychological, and / or behavioral deviations in organizational members.

\section{Leadership}

Leadership plays a role as a means to influence others or in this case the employees of the organization using decision-making skills in order to work together productively to achieve organizational goals and targets [8].

\section{Job satisfaction}

According to [9] job satisfaction is a feeling of whether or not the supports has been provided very well to the employees in relation to his job or his condition.

\section{Turnover}

Turnover is a process that employees will leave the organization and look for alternatives or other jobs that have not materialized in the form of real behavior [10].

\section{The Effect of Role Ambiguity on Job Satisfaction}

If the organization provides a work environment where the employees experience role ambiguity, employees will not be satisfied with their work because employees do not understand clearly in carrying out their duties and this can reduce job satisfaction and affect employee performance to achieve organizational goals and objectives [11]. Employees who are unable to get a part of the job and feel unable to understand instructions which ultimately make employees feel confused about their job descriptions will ultimately feel dissatisfied with their work [12].

\section{H1: Role ambiguity has a significant negative effect on job satisfaction}

\section{The Effect of Job Stress on Job Satisfaction}

Stress will trigger tension which greatly affects economic conditions and employee thought processes [13]. Work stress experienced by employees will affect organizational conditions because employee productivity decreases and reduces the level of employee job satisfaction [14].

\section{H2: Job stress has a significant negative effect on job satisfaction}

\section{The Effect of Leadership on Job Satisfaction}

Good leadership in the organization will make the organization have a good and conducive work culture that will create job satisfaction in employees [8]. 
H3: Leadership has a significant positive effect on job satisfaction

\section{The Effect of Role Ambiguity on Turnover}

Unwanted work situations are the main reason employees seek other organizations to work for [15]. Employees who feel frustrated because of the lack of information they receive about their role in the organization will lead them to feel insecure about their ability to complete their work and negative feelings that cause role ambiguity among these employees and will encourage them to leave the organization where they work [16].

\section{H4: Role ambiguity has a significant positive effect on turnover}

\section{The Effect of Job Stress on Turnover}

The high intention of turnover is caused by high work stress and a lot of work demands. According to the stress theory, psychosocial stress such as job role stress, lack of supervisor control, lack of social support and workplace interactions can have harmful effects on employees' health and eventually will affect the organizational income [17].

\section{H5: Job stress has a significant positive effect on turnover}

\section{The Effect of Leadership on Turnover}

Leadership is very influential on turnover. Employees who feel job dissatisfaction before having the intention to leave the organization will have the intention to leave the organization when they feel dissatisfied with their work and this is where the role of the leader is very influential in reducing the level of dissatisfaction, if the leadership in the organization is good it tends to help employees to stay in the organization [18].

\section{H6: Leadership has a significant negative effect on turnover}

\section{Effect of Job Satisfaction on Turnover}

Job satisfaction will be seen when employees can carry out their duties and jobs properly and produce work that is relatively in accordance with the expectations of the organization and this will form a commitment within employees to continue to work well and perform well which will ultimately stop the desire to leave. From jobs and organizations that have provided job satisfaction [18].

H7: Job satisfaction has a significant negative effect on turnover

\section{Conceptual Frameworks}

The theoretical framework in this study can be described as follows:

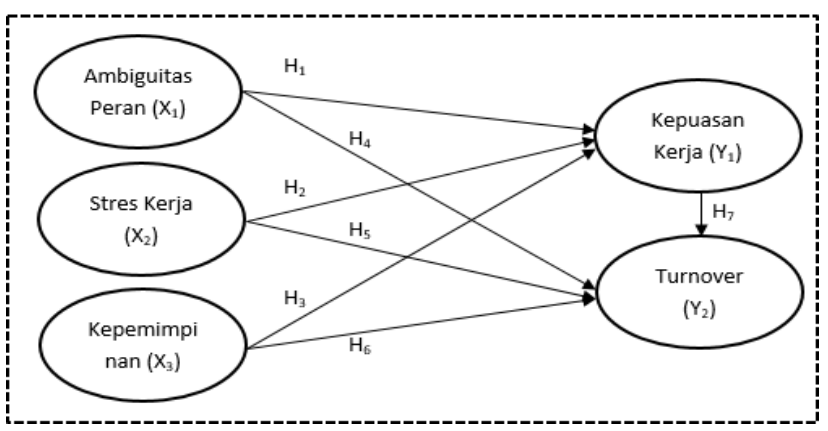

Fig-2: Conceptual Framework

\section{METHODOLOGY}

Sources and Type of Data

The independent variables in this study are Role Ambiguity (X1), Job Stress (X2), Leadership (X3) and the dependent variables are Job Satisfaction (Y1) and Turnover (Y2). The population in this study are employees of PT. Bank BRI Syariah Samarinda, in total of 89 employees. The sample in this study are all of the employees of PT. Bank BRI Syariah Samarinda.

\section{Measurement of Variables}

The following are variable items used in this study: 
Table-2: Research Variables

\begin{tabular}{|l|l|l|}
\hline No. & Variable & Item \\
\hline 1. & $\begin{array}{l}\text { Role Ambiguity } \\
\left(\mathrm{X}_{1}\right)\end{array}$ & $\begin{array}{l}\text { Owned authority. } \\
\text { Goals and objectives. } \\
\text { Time management. } \\
\text { Responsibility. } \\
\text { Hope. }\end{array}$ \\
\hline 2. & Job stress $\left(\mathrm{X}_{2}\right)$ & $\begin{array}{l}\text { Demands duties. } \\
\text { Role demands. } \\
\text { Interpersonal demands. } \\
\text { Organizational structure. }\end{array}$ \\
\hline 3. & Leadership $\left(\mathrm{X}_{3}\right)$ & $\begin{array}{l}\text { Bosses are willing to listen to employee problems related to work. } \\
\text { The boss can be relied on when the job is difficult. } \\
\text { Bosses are willing to provide assistance when employees find it difficult to do tasks at the } \\
\text { company. } \\
\text { Bosses accept suggestions given by employees. } \\
\text { Bosses involve employees in making decisions, especially decisions that affect the position } \\
\text { of employees in the organization. }\end{array}$ \\
\hline 4. & $\begin{array}{l}\text { Job satisfaction } \\
\left(Y_{1}\right)\end{array}$ & $\begin{array}{l}\text { Compensation. } \\
\text { Appreciation from superiors in carrying out tasks. } \\
\text { Fairness in opportunities for promotion. } \\
\text { In a short period of time he received a promotion. }\end{array}$ \\
\hline 5. & Turnover $\left(\mathrm{Y}_{2}\right)$ & $\begin{array}{l}\text { The possibility of employees working for the same organization in the next year. } \\
\text { The possibility for the employee to find another job in another organization. } \\
\text { Employees' desire to stay in the same organization for the next 5 years. }\end{array}$ \\
\hline
\end{tabular}

Source: Data processed, 2020

\section{RESULTS AND DISCUSSION}

\section{Evaluate the Outer Model}

The following is a test of the research model in this study:

Table-3: Research Model Test

\begin{tabular}{|l|l|l|}
\hline Information & Score & Ideal \\
\hline Average path coefficient (APC) & $\mathrm{p}=0,001$ & $<=0,05$ \\
\hline Average R-squared (ARS) & $\mathrm{p}=0,001$ & $<=0,05$ \\
\hline Average adjusted R-squared (AARS) & $\mathrm{p}=0,001$ & $<=0,05$ \\
\hline Average block VIF (AVIF) & 1,208 & $<=3,3$ \\
\hline Average full collinearity VIF (AFVIF) & 1,455 & $<=3,3$ \\
\hline Sympson's paradox ratio (SPR) & 0.857 & $>=0,7$ \\
\hline R-squared contribution ratio (RSCR) & 1 & $>=0,7$ \\
\hline Statistical suppression ratio (SSR) & 0,929 & $>=0,7$ \\
\hline Nonlinear bivariate causality direction ratio (NLBCDR) & $\mathrm{p}=0,001$ & $<=0,05$ \\
\hline
\end{tabular}

Source: Data processed, 2020 (WarpPLS 7.0)

Based on Table-3, it can be seen that each value at APC $(0.001<0.05)$, ARS $(0.001<0.05)$, AARS $(0.001<0.05)$, AVIF $(1.208<3.3)$, AFVIF $(1.455<3.3)$, SPR (0.857> 0.7), SSR (1>0.7), NLBCDR (0.929> $0.7)$. This value has met the ideal criteria. These results also indicate that the overall model of this research is appropriate (good). Before a research model is analyzed, the empirical research model is tested first and is described as follows: 


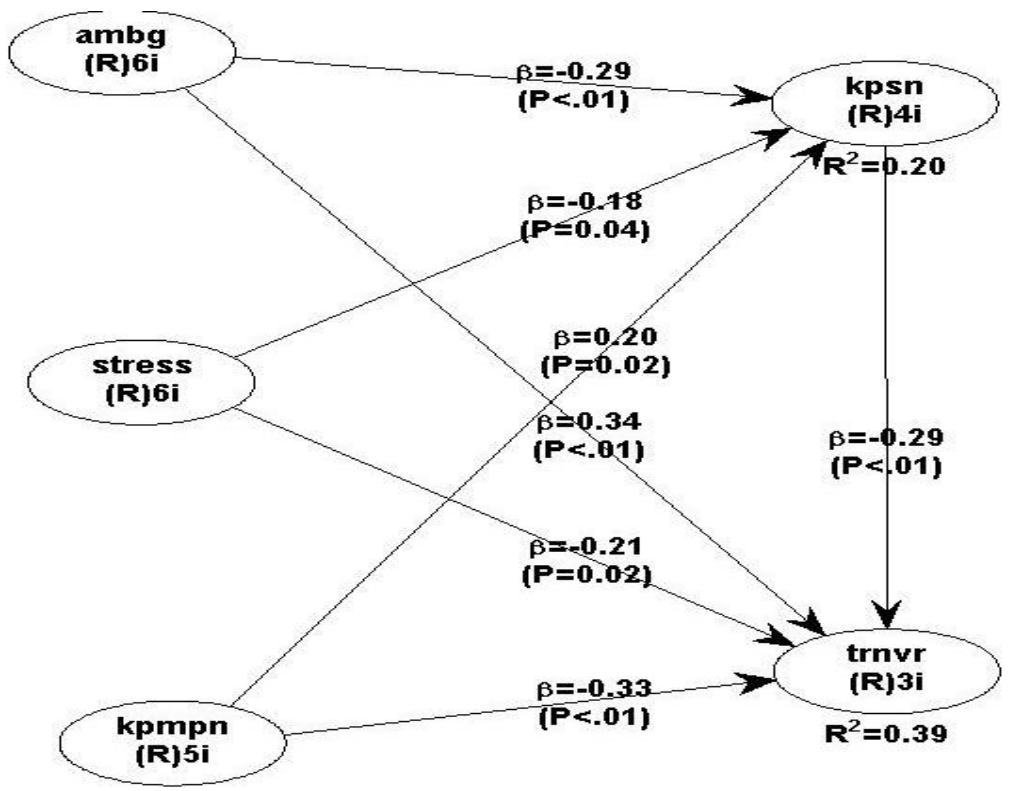

Fig-3: Structural Model

There are three criteria in the use of data analysis techniques with WarpPLS 7.0 to assess the outer model which are Convergent Validity, Discriminant Validity and Composite Reliability.

Validity Test

The validity test aims to show the suitability of each indicator in a construct. The criterion for the validity test is to see the loading factor value with a value of more than 0.60 and Average Variance Extracted (AVE) provided that if it is more than 0.50 for the convergent validity test and for the discriminant validity test using the root comparison of AVE with correlation between variables. The results of the validity test in this study are as follows:

Table-4: Initial Cross Loading Factor

\begin{tabular}{|c|c|c|c|}
\hline Variable & Indicator & Outer Loading & Information \\
\hline \multirow[t]{6}{*}{ Role Ambiguity $\left(\mathrm{X}_{1}\right)$} & $\mathrm{X} 1.1$ & 0,747 & Valid \\
\hline & $\mathrm{X} 1.2$ & 0,784 & Valid \\
\hline & $\mathrm{X} 1.3$ & 0,773 & Valid \\
\hline & $\mathrm{X} 1.4$ & 0,867 & Valid \\
\hline & $\mathrm{X} 1.5$ & 0,765 & Valid \\
\hline & $\mathrm{X} 1.6$ & 0,728 & Valid \\
\hline \multirow[t]{5}{*}{ Job stress $\left(\mathrm{X}_{2}\right)$} & $\mathrm{X} 2.1$ & 0,910 & Valid \\
\hline & $\mathrm{X} 2.2$ & 0,974 & Valid \\
\hline & $\mathrm{X} 2.3$ & 0,914 & Valid \\
\hline & $\mathrm{X} 2.4$ & 0,972 & Valid \\
\hline & $\mathrm{X} 2.5$ & 0,659 & Valid \\
\hline \multirow[t]{5}{*}{ Leadership $\left(X_{3}\right)$} & $\mathrm{X} 3.1$ & 0,763 & Valid \\
\hline & $\mathrm{X} 3.2$ & 0,787 & Valid \\
\hline & X3.3 & 0,920 & Valid \\
\hline & X3.4 & 0,940 & Valid \\
\hline & $\mathrm{X} 3.5$ & 0,886 & Valid \\
\hline \multirow[t]{3}{*}{ Job satisfaction $\left(\mathrm{Y}_{1}\right)$} & Y1.1 & 0,959 & Valid \\
\hline & Y1.2 & 0,943 & Valid \\
\hline & Y1.3 & 0,616 & Valid \\
\hline \multirow[t]{3}{*}{ Turnover $\left(\mathrm{Y}_{2}\right)$} & Y2.1 & 0,786 & Valid \\
\hline & Y2.2 & 0,904 & Valid \\
\hline & Y2.3 & 0,796 & Valid \\
\hline
\end{tabular}

Source: Data processed, 2020 (WarpPLS 7.0)

In Table- 4 it can be seen that each value on the cross loading has reached a value above 0.60 . Thus the prerequisites for the convergent validity test have been met. 
Salika Azzahra et al., Saudi J Bus Manag Stud, Jan, 2021; 6(1): 15-23

\section{Disriminant Validity}

Discriminant validity is used to ensure that each concept of latent variable is different from other variables. The model has a good discriminant validity if each loading value of each indicator of a latent variable has the greatest loading value with other loading values against other latent variables. The results of discriminant validity testing were obtained as follows:

Table-5: Discriminant Validity

\begin{tabular}{|l|l|l|l|l|l|}
\hline & Role Ambiguity & Job stress & Leadership & Job satisfaction & Turnover \\
\hline Role Ambiguity & 0,779 & & & & \\
\hline Job stress & 0,369 & 0,893 & & & \\
\hline Leadership & $-0,372$ & $-0,549$ & 0,862 & & \\
\hline Job satisfaction & $-0,132$ & $-0,261$ & 0,191 & 0,854 & \\
\hline Turnover & 0,490 & $-0,205$ & $-0,401$ & $-0,210$ & 0,830 \\
\hline
\end{tabular}

Source: Data processed, 2020 (WarpPLS 7.0)

In Table-5, it can be seen that the root AVE value for each variable is higher than the AVE value for the other variables. This shows that the prerequisites for the discriminant validity test have been met. Thus the instrument used in this study has met the requirements of the validity test. The validity criteria can also be seen from the Average Variance Extracted (AVE) value of each construct. The construct have high validity if the AVE value is above 0.50 [19]. Table-6 presents the AVE values for all variables:

Table-6: Average Variance Extracted

\begin{tabular}{|l|l|l|}
\hline Variable & AVE $\mathbf{( > 0 , 5 0 )}$ & Information \\
\hline Role Ambiguity & 0,606 & Valid \\
\hline Job stress & 0,798 & Valid \\
\hline Leadership & 0,743 & Valid \\
\hline Job satisfaction & 0,689 & Valid \\
\hline Turnover & 0,729 & Valid \\
\hline
\end{tabular}

Source: Data processed, 2020 (WarpPLS 7.0)
Based on the results of the data presentation in table 6 , the average variance extraced (AVE) value is greater than 0.50 (AVE> 0.50). Based on the test results above, it can be concluded that the construct has good convergent validity. The AVE value is the value that comes from the outer loading of each indicator for each variable. AVE value that is greater than 0.50 illustrates good validity.

\section{Reliability Test}

The reliability test in this study can be seen on the composite reliability and can be strengthened by using the Cronbach alpha value. The variable is reliable if it has a composite reliability value of more than 0.70 .

Table-7: Reliability Test

\begin{tabular}{|l|l|l|l|}
\hline Variable & $\begin{array}{l}\text { Composite Reliability } \\
(>\mathbf{0 , 7 0 )}\end{array}$ & $\begin{array}{l}\text { Cronbach Alpha } \\
(>\mathbf{0 , 6 0 )}\end{array}$ & Information \\
\hline Role Ambiguity & 0,902 & 0,636 & Reliable \\
\hline Job stress & 0,906 & 0,924 & Reliable \\
\hline Leadership & 0,935 & 0,955 & Reliable \\
\hline Job satisfaction & 0,869 & 0,818 & Reliable \\
\hline Turnover & 0,760 & 0,900 & Reliable \\
\hline
\end{tabular}

Source: Data processed, 2020 (WarpPLS 7.0)

In Table-7, it can be seen that the composite reliability value of all research variables is greater than 0.70 and Cronbach's alpha is greater than 0.60. These results indicate that each variable has met the prerequisite for reliability, so it can be concluded that all variables have a good level of reliability.

\section{Inner Model Evaluation}

The inner model test or structural model is done to see the relationship between the constructs, the significance value and the $\mathrm{R}$-square of the research model. The structural model was evaluated using the Rsquare for the dependent construct of the $t$ test and the significance of the structural path parameter coefficients. 


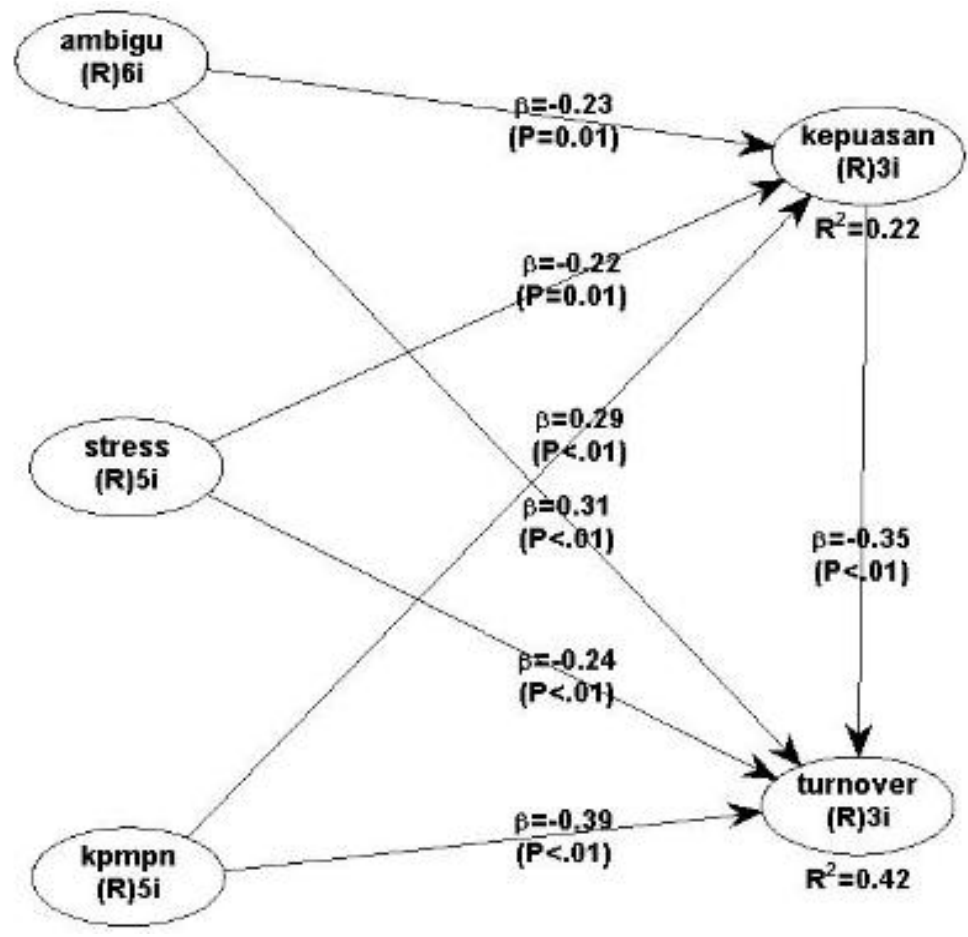

Fig-4: Structural Model

In assessing the model using PLS, it starts by looking at the R-square for the dependent latent variable and the Q-square for predictive relevance. Table-8 shows the values of R-Square and Q-Square for job satisfaction and turnover variables.

Table-8: R-Square

\begin{tabular}{|l|l|l|}
\hline Variable & R-Square & Q-Square \\
\hline Job satisfaction & 0,220 & 0,201 \\
\hline Turnover & 0,420 & 0,613 \\
\hline
\end{tabular}

Source: Data processed, 2020 (WarpPLS 7.0)

In Table- 8 it can be seen that the R-Square value on the job satisfaction variable is 0.220 and the turnover is 0.420 . This shows that:

1. The value of 0.220 means that the variable job satisfaction is influenced by ambiguity, job stress, and leadership by $22 \%$.
2. Value 0.420 means that the Turnover variable is influenced by Ambiguity, Work Stress, and Leadership by $42 \%$.

In Table-8, it can be seen that Q-Square on the job satisfaction variable is 0.201 and the turnover is 0.613. The value of $\mathrm{Q}^{2}>0$ indicates evidence that the observed values have been reconstructed properly, so that the model has predictive relevance.

\section{Hypothesis Test}

The significance of the modified parameters provides information about the relationship between the research variables. The basis used in testing the hypothesis is the value contained in the output path coefficients. Table- 9 provides the modified output for structural model testing.

Table-9: Hypothesis Test

\begin{tabular}{|l|l|l|l|}
\hline Information & Coefficient & p-value & Result \\
\hline Role Ambiguity => Job satisfaction & $-0,230$ & 0,011 & Significant \\
\hline Job stress => Job satisfaction & $-0,220$ & 0,015 & Significant \\
\hline Leadership => Job satisfaction & 0,290 & 0,002 & Significant \\
\hline Role Ambiguity => Turnover & 0,310 & 0,001 & Significant \\
\hline Job stress => Turnover & $-0,236$ & 0,010 & Significant \\
\hline Leadership => Turnover & $-0,386$ & 0,001 & Significant \\
\hline Job satisfaction => Turnover & $-0,350$ & 0,001 & Significant \\
\hline
\end{tabular}

Source: Data processed, 2020 (WarpPLS 7.0)

Based on Table-9, it can be seen the results of hypothesis testing in this study. The interpretation of the results of the hypothesis testing is as follows:
1. The effect of role ambiguity on job satisfaction has a significance level of 0.011 . Where the significant value is less than $0.05(0.011<0.05)$. And the 
Salika Azzahra et al., Saudi J Bus Manag Stud, Jan, 2021; 6(1): 15-23

regression coefficient in negative direction. Thus it can be concluded that role ambiguity has a significant negative effect on job satisfaction.

2. The effect of job stress on job satisfaction has a significance level of 0.015 . Where the significant value is less than $0.05(0.015<0.05)$. And the regression coefficient in negative direction. Thus it can be concluded that job stress has a significant negative effect on job satisfaction.

3. The influence of leadership on job satisfaction has a significance level of 0.002 . Where the significant value is less than $0.05(0.002<0.05)$. And the regression coefficient is in a positive direction. Thus it can be concluded that leadership has a significant positive effect on job satisfaction.

4. The effect of role ambiguity on turnover has a significance level of 0.001 . Where the significant value is less than $0.05(0.001<0.05)$. And the regression coefficient is in a positive direction. Thus it can be concluded that role ambiguity has a significant positive effect on turnover.

5. The effect of job stress on turnover has a significance level of 0.010 . Where the significant value is less than $0.05(0.010<0.05)$. And the regression coefficient in negative direction. Thus it can be concluded that job stress has a significant negative effect on turnover.

6. The influence of leadership on turnover has a significance level of 0.001 . Where the significant value is less than $0.05(0.001<0.05)$. And the regression coefficient in negative direction. Thus it can be concluded that leadership has a significant negative effect on turnover.

7. The effect of satisfaction on turnover has a significance level of 0.001 . Where the significant value is less than $0.05(0.001<0.05)$. And the regression coefficient in negative direction. Thus it can be concluded that job satisfaction has a significant negative effect on turnover.

\section{CONCLUSION}

Based on the results of the study, it can be concluded that the role of superiors and organizational management is needed to provide the best guidance, especially for new employees in order to understand the main duties and positions held in the organization which will prevent employees from experiencing role ambiguity.

\section{REFERENCES}

1. Pricewaterhouse, C. I. (2020). Indonesia Banking Survey. Retreived November 3, 2020, from https://www.pwc.com/id/en/publications/pwcindonesiabanking-survey-2013.pdf.

2. Amrizal. (2016). Quantitative and Qualitative Approach of Banking Performance Measure Based on Job Satisfaction for Islamic and Conventional Banks in Indonesia. Jurnal Balance, 8(2), 63-81.

3. Arvindraj \& Shanmugam, J. K. (2019). Factors Influencingh Employee's Turnover Intention in
Banking Sector in Penang. E-Academia Journal, 8(2), 41-55.

4. Qureshi, M. I., Jamil, R. A., Arif, S., Naseem, I., \& Zaman, K. (2012). Job Stress, Workload, Environment and Employees Turnover Intentions: Destiny or Choice. Archives Des Sciences, 65(8), 230-241.

5. Khattak, M. A., Urooj, S. F., Khattak, J., \& Iqbal, N. (2011). Impact of Role Ambiguity on Job Satisfaction: Mediating Role of Job Stress. International Journal of Academic Research in Business and Social Sciences, 1(3), 516-531.

6. Letchumanan, T., Apadore, K., \& Ramasamy, M. (2017). Factors Influence Turnover Intention in Commercial Banks Malaysia: A Theoretical Modul. Innovative Journal of Business and Management, 6(3), 13-21.

7. Luthans, F. (2011). Organizational Behavior: An Evidence-Based Apporach. Boston: McGraw-Hill Irwin.

8. Hidayati, S. N., \& Saputra, S. D. (2018). Pengaruh Kepemimpinan, Kompensasi, Komunikasi dan Motivasi Kerja Terhadap Turnover Intention Pegawai Dengan Kepuasan Kerja Sebagai Variabel Antara. Jurnal Maksipreneur, 7(2), 162173.

9. Yulk, G. (2010). Kepemimpinan Dalam Organisasi. $5^{\text {th }}$ edition. Jakarta: PT. Indeks.

10. Etnaningtiyas, A. P. (2011). Faktor-Faktor Yang Mempengaruhi Intensi Turnover Pada Karyawan PT. Alenatex Bandung. Fakultas Psikologi Universitas Islam Negeri Syarif Hidayatullah Jakarta.

11. David, Y., Syed, S., Zaini, A., \& Nilufar, A. (2009). A Study of Job Stress on Job Satisfaction among University Staff in Malaysia: Empirical Study. European Journal of Social Sciences, 8(1), 121-129.

12. Alshery, W. B. R., Ahmad, F. B., \& Al-Swidi, A. K. (2015). The Moderating Effect of Role Ambiguity on the Relationship of Job Satisfaction, Training and Leadership with Employee Performance. International Journal of Business Administration, 6(2), 30-41.

13. Damayanthi, E. L. (2015). Hubungan Antara Stres Kerja dan Motivasi Kerja Dengan Kinerja Karyawan. Persona, Jurnal Psikologi Indonesia, 4(1), 44-50.

14. Chaudhry, M. S., Sabir, H. M., Rafi, N., \& Kalyar, M. N. (2018). Exploring the Relationship Between Salary Satisfaction and Job Satisfaction: A Comparison of Public and Private Sector Organizations. The Journal Commerce, 3(4), 1-14.

15. Jung, J., \& Kim, Y. (2012). Causes of Newspaper Firm Employee Burnout in Korea and Its Impact on Organizational Commitment and Turnover Intention. The International Journal of Human Resource Management, 23(17), 3636-3651.

16. Clereq, D. D., Belausteguigoitia, I. (2017). Reducing the Harmful Effect of Role Ambiguity 
Salika Azzahra et al., Saudi J Bus Manag Stud, Jan, 2021; 6(1): 15-23

on Turnover Intentions The Roles of Innovation Propensity, Goodwill Trust, and Procedural Justice. Personnel Review, 46(6), 1046-1069.

17. Arshandi, N., \& Damiri, H. (2013). The Relationship of Job Stress with Turnover Intention and Job Performance: Moderating Role of OBSE. Social and Behavioral Sciences, 84, 706-710.

18. Paaisal, L. O. R., Tabroni \& Maksum, C. (2018). Pengaruh Gaya Kepemimpinan dan Budaya
Organisasi Terhadap Turnover Melalui Kepuasan Kerja karyawan Pada PT. Mutiara Wisesa Samudra di Jakarta. Jurnal Eksekutif, 15(6), 191215.

19. Ghozali, I., \& Lathan, H. (2014). Partial Least Squares: Konsep, Teknik dan Aplikasi Menggunakan Program WarpPLS 4.0. $2^{\text {nd }}$ edition. Semarang: Universitas Diponegoro. 